\title{
Ecologically conditioned imprinting of miRNA-based profiles of Ginkgo biloba L. growing in Slovakia
}

\author{
Katarína Ražná1* , Jana Žiarovská1, Pavel Hrubík ${ }^{2}$, Veronika Batyaneková1, \\ Angela Vargaová ${ }^{1}$ \\ ${ }^{1}$ Department of Genetics and Plant Breeding, Faculty of Agrobiology and Food Resources, Slovak University of \\ Agriculture in Nitra, Trieda Andreja Hlinku 2, 94976 Nitra, \\ Slovak Republic \\ ${ }^{2}$ Dunajská 16, 94911 Nitra, Slovak Republic
}

\begin{abstract}
RaŽnÁ, K., Žiarovská, J., Hrubík, P., Batyaneková, V., Vargaová, A., 2019. Ecologically conditioned imprinting of miRNA-based profiles of Ginkgo biloba L. growing in Slovakia. Folia Oecologica, 46: 54-62.

Ginkgo biloba L. is characterized by its high level of resistance to climatic conditions, diseases, and pests. In Slovakia, there is a rich collection of genetic resources of ginkgo consisting of 288 trees growing in 103 locations and providing valuable biological material for scientific research. There have been documented 45 trees of ginkgo older than 100 years (ranging from 112 to 242 years of age). Their dendrometrical parameters were recorded. For genomic imprinting, three types of microRNA-based markers were selected; highly conserved gb-miR160, moderately conserved gb-miR482 and the species-specific gb-miR75. The most efficient one can be considered the marker gb-miR482 with its genotype-unique miRNA profiles probably related to this marker functioning in the defence mechanisms of the ginkgo species. Unique miRNA loci were recorded in genomes of young ginkgo trees. We found that, by selecting the appropriate microRNA-based markers, it is possible to characterize the ginkgo genome in the context of microclimatic conditions.
\end{abstract}

Keywords

Ginkgo, locality, molecular markers, Slovakia

\section{Introduction}

Ginkgo biloba $\mathrm{L}$. is the oldest tree species on our planet. It is characterized by extreme resistance to climate changes and natural influences. It is the only living member of the family Ginkgoaceae. Because of all its properties, it has been associated with longevity and a powerful life-force, as well as strong production of new branches. The tree is heliophilous, and frost-resistant (excluding young seedlings and juvenile trees). Its growth is slow and irregular (in some years there is a minimum increment). It has a strong wheel root and exhibits good tolerance against cutting.

G. biloba L. leaves are a source of a number of medicines that are mainly used for central and peripheral circulatory disorders. In many European countries, registered ginkgo formulations are the most commonly prescribed drugs based on plant extracts. They are used for treatment of cerebral ischaemia, peripheral vascular disorders and neurosensing disorders (ZitTLAU, 2007). Extracts are pre-

\footnotetext{
*Corresponding author: e-mail: katarina.razna@uniag.sk 
pared from leaves, the most widely used one is called EGb 761. The most important extracts both in terms of quantity and effectiveness are flavonoids and terpene trilactones (ginklodide and bilobalide) (MoHANTA et al., 2012).

The origin of ginkgo is in Eastern China, on a small territory of Tianmu San located in the mountains of the province Zhejiang. Since the 11th century, this plant has been grown in North China, Korea, Japan, often planted at temples, Buddhist and Taoist monasteries, and palaces (Begovic, 2010; VAn BeEK, 2000). Apart from this native area, elsewhere in Europe and America, the species exhibits a cultural area of expansion through action of man, most often by transferring seeds and plant parts for vegetative reproduction (various shape and colour varieties are obtained by grafting, vegetative form).

In Slovakia, there is a rich collection of genetic resources of G. biloba L., grown in historical parks, botanical gardens, arboretums, green areas of towns and villages and other dendrological areas (RAŽNÁ et al., 2014; RAŽNÁ and HRUBík, 2016). As for planting, the ginkgo species is becoming more and more popular with its colourful and ornamentally shaped cultivars occupying more and more space in family gardens. However, the major prospect of the alley cultivars of G. biloba is their planting in urban greenery, especially in street alleys.

The ginkgo genome is of high scientific interest for its exclusive properties (LIN et al., 2011). The genomic research on G. biloba includes; (a) the identification of markers for sex identification - to support field planting of ginkgo (LiAO et al., 2009; YANG et al., 2005), (b) cultivar identification - to contribute to the conservation, genetic diversity and mating patterns (FAN et al., 2004; LI and ZHANG, 2013; LI et al., 2009; MeI et al., 2014; YAN et al., 2006; YAN et al., 2009), (c) the high-throughput genomic research (HAN et al., 2015; He et al., 2015; LIN et al., 2011) and (d) the comparison of the genomes of the species of G. biloba identified in Slovakia and abroad, characterization of morphological gender differences, and peculiarities within the species (RAŽNÁ et al., 2014; RAŽNÁ and HRUBÍK, 2016). ŠMARDA et al. (2016) observed the polyploidy of the ginkgo genome, which is quite unusual in gymnosperms. Ginkgo has the potential to form spontaneous polyploidy offspring, which may represent one of the ways how this ,living fossil“" is surviving different environmental conditions. There has been found a surprisingly high ploidy variation in modern-day ginkgo (ŠMARDA et al., 2018).

MicroRNAs are endogenous, single-stranded, noncoding molecules of about 21-25 nt in size, playing an important regulatory role in plant growth and development (BARVKAR et al., 2013; KrUSZKA et al., 2012), biological and metabolic processes (WANG et al., 2012) and various developmental and physiological processes (BEJ and BASAK, 2014; JoNEs-RhOADES et al., 2006). MicroRNAs regulate posttranscriptional expression by repression of translation or target gene degradation and subsequent gene silencing (BARTEL, 2004; NeUtelings et al., 2012). WANG et al. (2015), sequencing of cDNA of male and female leaves, identified short molecules of the ginkgo genome. These authors identified 202 (in female leaves) and 201 (in male leaves) of the known miRNAs, which were subsequently categorized into 82 or 78 classes, respectively. At the same time, within the two libraries, the authors identified 174 new miRNA molecules. Most miRNAs identified represent miRNA classes that are of a highly conserved nature, e.g. miR160, miR166, miR396, miR159, miR171, miR408, miR167, miR168 and miR398. These classes have specific functions in the various physiological processes in the plants. The second most frequent category is medium conserved miRNA, e.g. miR482/448, miR529, miR2118 and miR535. The last category consists of species-specific miRNAs, e.g. miR1220, miR5225, miR1314, miR2873, miR950, miR4376, miR5240, miR5261 and miR5301, important in originating new functions (WANG et al., 2015). The target sequences of the identified microRNA predominated those related to the regulation of defence processes and disease resistance as well as the regulation of the biosynthetic processes of the secondary metabolites.

DNA-based markers corresponding to miRNA sequences have been developed as a new type of functional markers (Fu et al., 2013). MicroRNAs-based molecular markers represent a new, highly efficient, stable, reproducible and protocol-portable method of genotyping in the area of marker techniques (Fu et al., 2013; YADAV et al., 2014). A system of genotyping based on miRNAs markers was applied to Brassica sp. (Fu et al., 2013), Setaria sp. (YADAV et al., 2014) as well as to rice (GANIE and MonDAL, 2015; Mondal and GANIE, 2014). MicroRNA markers combine the advantages of relatively high polymorphism, reproducibility, inter-species transferability, and ease of use with predicted functionality. The effectiveness of miRNA markers depends on the genetic and evolutionary proximity of the studied species. Since these markers are derived from conserved miRNAs sequences, a high degree of versatility between the genes is expected. A high degree of portability is evidence of the utility of miRNAs markers as markers for comparative mapping of the genome and understanding the phylogeny between different crop species (YADAV et al., 2014). MiRNAs-based primers combined with different sites on the same loop can produce fragments of useful size for genotyping. Polymorphism amplified by the application of miRNAs markers indicates changes in miRNA loci sequences, which may result in changes in the target gene regulation.

The aim of our study was focused on dendrometrical characterization and the age determination of the oldest ginkgo trees grown in Slovakia, and, at the same time, on characterization of their genome polymorphism by microRNA-based molecular markers in the context of microclimatic conditions. MiRNAs markers can serve as functional markers and they can also be used to detect 
the connection between the microclimatic conditions of growth and the genome adaptability of trees, especially old ones.

\section{Materials and methods}

\section{Dendrometrical and age parameters of ginkgo trees}

In the dendrometrical characterization of the Ginkgo biloba L., the best practices and methodologies were followed. The research has comprised the full list of the known and published localities (BENČAŤ, F., 1982), including extra new sites obtained from other sources (RAŽNÁ et al., 2014; RAŽNÁ and HRUBíK, 2016).

At each evaluated locality, all the existing ginkgo trees were examined. There were measured their basic taxonomic variables (trunk circumference, trunk diameter $1.3 \mathrm{~m}$ above ground, tree height, crown width, health status and horticultural value) (HRUBík et al., 2011). In the case of larger trees, there was also traced the circumference of the stem to the ground, and taken the current photo documentation of the trees on the particular site.

The tree height was measured with a SUUNTO altimeter; crown width was measured in two perpendicular directions according to the crown shape (most trees were solitaires with a regular crown); the tree sex was identified based on the flowers, fruits, habitus and the angle of the lateral branches. The diameter of the tree stem (at a height of $1.3 \mathrm{~m}$ ) was measured directly, with a textile band measuring the trunk circumference in $\mathrm{cm}$. Detecting the tree age is mostly difficult, especially for rare and valuable species (which is undoubtly the case og ginkgo in our conditions). Although core samples were taken with a Pressler borer from all the trees evaluated, the following dendrochronological evaluation of these samples was unacceptable for financial reasons. Therefore, we used the published mathematical formula: $V=(5 /[\pi \times R L])$ $\times d$, where $\mathrm{d}$ is the stem diameter (in $\mathrm{cm}$ ) at $\mathrm{d} 1.3 \mathrm{~m}$; RL is the width of the ring (in $\mathrm{cm}$ ), for the gingko the value is 2.530 (KolǍ̌́́K et al., 2010).

\section{Sampling and sample preparation}

G. biloba $\mathrm{L}$. leaves were collected from selected localities in Slovakia and stored at $-50^{\circ} \mathrm{C}$ until they were analysed. All the trees sampled were healthy and genetically grown from seeds. The list of samples for genomic analyses is shown in Table 1.

\section{Genomic analysis}

The total genomic DNA was extracted from leaves homogenized in liquid nitrogen in accordance with the protocol by Padmalantha and Prasad (2006). The extracted DNA was quantified by the Implen NanoPhotometer ${ }^{\circledR}$, and diluted to $70 \mathrm{ng} \mu \mathrm{l}^{-1}$.

In order to explore the genomic imprinting of ginkgo trees in regard to their age and locality, four types of microRNAs markers have been used. These markers were selected based on the study of WANG et al. (2015), representing different families of miRNA sequences. The sequences of the following microRNA markers were used: deeply conserved - gb-miR160; moderately conserved gb-miR482; species-specific - gb-miR5261 and the novel miRNA family - gb-miR75. The sequences of the primers used for the amplification of the individual markers are presented in Table 2.

Genomic analyses were performed based on studies by Fu et al. (2013) and YADAV et al. (2014) with modifications (RAŽNÁ et al., 2015; HLAVAČKOvá et al., 2016). PCR was amplified in a PCR mix $20 \mu \mathrm{L}$ containing 70 ng of genomic DNA, 10 pmol dm ${ }^{-3}$ of each primer, $2 \mathrm{U}$ of DreamTaq DNA polymerase, $0.8 \mathrm{mmol} \mathrm{\textrm {dm } ^ { - 3 } \mathrm { dNTPs }}$ (Bioline) and $1 \times$ DreamTaq Buffer $\left(\mathrm{KCl},(\mathrm{NH} 4)_{2} \mathrm{SO}_{4}, 20\right.$ mmol dm ${ }^{-3} \mathrm{MgCl}_{2}$ ). The PCR amplification programme used the 'touchdown' method as follows: initial denaturation at $94{ }^{\circ} \mathrm{C}$ for $5 \mathrm{~min} ; 5$ cycles of $30 \mathrm{~s}$ at $94{ }^{\circ} \mathrm{C}, 45 \mathrm{~s}$ at $64{ }^{\circ} \mathrm{C}$ (with a $1{ }^{\circ} \mathrm{C}$ decrease in annealing temperature per cycle), and $60 \mathrm{~s}$ at $72{ }^{\circ} \mathrm{C} ; 30$ cycles of $30 \mathrm{~s}$ at $94^{\circ} \mathrm{C}, 45 \mathrm{~s}$ at $60{ }^{\circ} \mathrm{C}$, and $60 \mathrm{~s}$ at $72{ }^{\circ} \mathrm{C}$; and the final extension at $72{ }^{\circ} \mathrm{C}$ for $10 \mathrm{~min}$. The samples were subsequently stored at $8^{\circ} \mathrm{C}$.

Table 1. The list of ginkgo trees samples used for genomic analyses

\begin{tabular}{cccc}
\hline Sample number & Locality & Gender & Age (years) \\
\hline 1. & Nová Ves nad Žitavou & Female & 140 \\
2. & Topol’čianky & Male & 155 \\
3. & Lučenec & Female & 135 \\
4. & Vel'ký Blh & Female & 96 \\
5. & Hnúšt'a & Male & 134 \\
6. & Rimavská Sobota & Female & 68 \\
7. & Hokovce & Male & 112 \\
8. & Palárikovo & Male & 160 \\
9. & Šrianky & Male & 44 \\
10. & Košice & Male & 193 \\
11. & Budimír & Male & 79 \\
12. & Prešov & Male & 133
\end{tabular}


Table 2. Primers sequences used for miRNAs markers amplification

\begin{tabular}{cc}
\hline Primer & Sequences 5' 3 $^{\prime}$ \\
\hline gb-miR160 forward & TTAGTCTGCCTGGCTCCCTGTATG \\
gb-miR75 forward & TTCAGGGTGTTAGGTTTGGGAGAA \\
gb-miR75 reverse & CCGGGCAGTAGGAATGGGAGGAAT \\
gb-miR482P & TGGGTTGTAGTCTTCAGGAGTGGG \\
gb-miR482S & GAAGGCAATAGGAATGGGAGGATC \\
gb-miR5261P & TTTGGAAAGTATTCGCATTGATTA \\
gb-miR5261S & TATGGAACAAATTGCCACTCGGAT \\
\hline
\end{tabular}

The PCR products were separated using 15\% TBE-Urea polyacrylamide gels running in $1 \times$ TBE Running Buffer at a constant power $90 \mathrm{~V}, 25 \mathrm{~mA}$ for $120 \mathrm{~min}$. $10 \mathrm{bp}$ DNA ladder (Invitrogen) was used for the size comparison. The polyacrylamide gels were stained with the GelRed ${ }^{\mathrm{TM}}$ Nucleic Acid Gel stain and visualised in the G-Box Syngene electrophoresis documentation system. The gels were analysed by the GeneTools software - GeneSnap version 7.09 .17 (Syngene) in order to record the number of the loci and to identify the unique fragments.

\section{Statistical analysis}

The bands for each miRNA-based allele were scored in terms of their presence (1) or absence (0). The scored data were used for the estimation of the Jaccard' similarity coefficient and the similarity matrix was used in cluster analysis with the unweighted pair group method and arithmetic averages (UPGMA) according to GARCIA-VALLVE et al., 1999 (http://genomes.urv.cat/UPGMA/). The polymorphism information content (PIC) value was calculated based on Fu et al. (2013).

The hierarchical cluster trees (dendrograms) were constructed for each primer combination. The accuracy of the clustering based on our data was verified with use of the cophenetic correlation coefficient (CP). The closer the value of the $\mathrm{CP}$ is to 1 , the more accurately the clustering solution reflects the data.

\section{Results and discussion}

\section{The oldest trees of Ginkgo biloba L. in Slovakia}

The age detection of trees seemed to be the most difficult step, although there are several possibilities: an estimate through the tree growth; approximate estimates according to the period of establishment of the dendrological building, historical park or garden related.

These methods were considered to be relatively inaccurate, because they do not allow a more accurate identification of the planting year of the particular tree. Estimating the tree age by calculating the number of rings on the dendrometric cores cut with a Pressler borer also appears inaccurate and only approximate, even though we used this option especially for larger trees. Finally, for evaluating all the trees, we used a mathematical calculation ac- cording to the formula KolAŘík et al. (2010).

In some trees, especially younger (juvenile) individuals, the data on the tree age or the planting year are fairly accurate (it is necessary to add 5-10 years, from seed planting in a nursery to the delivery of seedlings capable of being planted directly in a specific location).

Based on these findings and practical experience, it is possible, with a certain time tolerance (20-40 years), to accept the results of calculating the age of ginkgo trees according to the aforementioned mathematical formula. A list of the oldest trees in Slovakia is presented in Table 3.

Recognizing the gender on young plants is also very intricate. Ginkgo gender identification is needed to support ginkgo cultivation by distinguishing between male and female trees having different economic and medicinal values (LiQIn et al., 2009).

In the available literature (van BEEK, 2000; BEGović, 2010), the gender of the G. biloba L. trees is determined based on morphological differences. Dendrometrical parameters also represent a significant approach of the study of tree species adaptability to deteriorating urban conditions (UHRIN et al., 2018) and mapping the cultural distribution of a species within a certain area in the context of microclimatic conditions (FEREZLIEV, 2017).

The tree gender can also be judged about according to the distribution of tree crowns: it holds in general that female trees have branches almost horizontally distributed (our findings, however, are just the opposite). According to the above mentioned data literature, seeds with two ribs (on stone-seed) produce female trees and those with three ribs produce male trees.

Leaves and short sprouts of female trees are larger and rounded; on males, they are smaller and conical. At the bottom of the trunk and also on the branches, especially after a plant injury, characteristic features emerge. Extending as stalactites and touching the earth, they are rooted (the Japanese name for these formations is "czi-czi" and this name has taken hold throughout the world) (BARLOW and KURCZYNSKA, 2007).

On the basis of several decades of ginkgo tree research as well as foreign expedition knowledge, there have been found the following differences the genders:

a) On male trees, the lateral branches leave the trunk at a right angle, on female trees at an acute angle.

b) The seeds with two ribs are produced male trees, and those with three ribs by female trees.

c) The beginning of flowering time in male trees is $2-3$ weeks earlier than in female trees. However, the entire 
Table 3. The list of the oldest trees of Ginkgo biloba L. in Slovakia and their dendrometrical parameters

\begin{tabular}{|c|c|c|c|c|c|c|}
\hline Locality & $\begin{array}{c}\text { Trunk } \\
\text { circumference } \\
(\mathrm{cm})\end{array}$ & $\begin{array}{c}\text { Trunk } \\
\text { diameter } \\
(\mathrm{cm})\end{array}$ & $\begin{array}{l}\text { Height } \\
\text { (m) }\end{array}$ & $\begin{array}{l}\text { Width of the } \\
\text { tree crown } \\
(\mathrm{m})\end{array}$ & $\begin{array}{c}\text { Gender tree } \\
(\hat{0},+,)\end{array}$ & Age \\
\hline Abramová & 238 & 76.0 & 14 & $18 \times 14$ & q & 121 \\
\hline Beladice & 259 & 82.5 & 18 & $16 \times 16$ & $\hat{\sigma}$ & 131 \\
\hline Beladice & 237 & 75.2 & 20 & $16 \times 16$ & q & 130 \\
\hline Betliar & 233 & 74.3 & 19 & $19 \times 14$ & 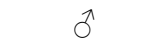 & 118 \\
\hline Bojnice & 276 & 87.9 & 21 & $10 \times 10$ & $\widehat{\sigma}$ & 140 \\
\hline Bojnice & 290 & 92.4 & 26 & $12 \times 12$ & $\widehat{\delta}$ & 147 \\
\hline $\begin{array}{c}\text { Bratislava, Botanická záhrada } \\
\text { UK }\end{array}$ & 222 & 70.7 & 16 & $8 \times 8$ & q & 112 \\
\hline Bratislava, Sady J. Král’a & 467 & 148.8 & 20 & $28 \times 24$ & q & 236 \\
\hline Častá (Červený Kameň) & 375 & 122.2 & 14 & $12 \times 14$ & 우 & 194 \\
\hline Galanta & 285 & 90.5 & 20 & $18 \times 20$ & $\widehat{\sigma}$ & 144 \\
\hline Hajná Nová Ves & 478 & 152.4 & 22 & $30 \times 30$ & q & 242 \\
\hline Hnúšt’a & 263 & 83.8 & 26 & $12 \times 15$ & $\hat{\sigma}$ & 134 \\
\hline Hokovce, súkromná záhrada & 220 & 70.1 & 25 & $12 \times 14$ & $\hat{0}$ & 112 \\
\hline Horenická Hôrka-Medné & 345 & 110.2 & 25 & $20 \times 20$ & q & 158 \\
\hline Horné Semerovce & 325 & 103.7 & 19 & $14 \times 10$ & $\widehat{\sigma}$ & 165 \\
\hline Humenné & 275 & 87.6 & 22 & $15 \times 20$ & q & 139 \\
\hline Janova Ves & 373 & 111.2 & 22 & $20 \times 20$ & $\hat{0}$ & 197 \\
\hline Jasov, Kláštorná záhrada & 220 & 70.2 & 14 & $14 \times 14$ & $\widehat{0}$ & 112 \\
\hline Kazimír & $229 ; 170$ & $73.0 ; 54.2$ & 17 & $22 \times 20$ & q & 116 \\
\hline Komjatice & 327 & 104.2 & 25 & $22 \times 22$ & q & 165 \\
\hline Košice, Masarykova ul.3 & 381 & 121.7 & 27 & $24 \times 12$ & $\widehat{\sigma}$ & 193 \\
\hline Košice, Park J.A.Komenského & 312 & 99.7 & 20 & $20 \times 20$ & $\hat{0}$ & 158 \\
\hline $\begin{array}{l}\text { Lučenec, Ipel'ské tehelne a.s., } \\
\text { cv.'Ohatsuki' }\end{array}$ & 267 & 85.1 & 22 & $16 \times 16$ & q & 135 \\
\hline Malý Šariš & $315 ; 285$ & $100.7 ; 91.0$ & 20 & $20 \times 20$ & $\hat{0}$ & 160 \\
\hline Nová Ves nad Žitavou & 277 & 88.3 & 18 & $22 \times 24$ & q & 140 \\
\hline Nová Ves nad Žitavou & 228 & 72.7 & 16 & $23 \times 20$ & q & 115 \\
\hline Palárikovo & 316 & 101.0 & 20 & $19 \times 19$ & $\hat{0}$ & 160 \\
\hline Palárikovo & 247 & 78.6 & 20 & $14 \times 14$ & $\hat{0}$ & 125 \\
\hline Piešt'any & 280 & 89.2 & 25 & $20 \times 20$ & $\hat{\sigma}$ & 142 \\
\hline Pohronský Ruskov & 261 & 83.2 & 14 & $23 \times 20$ & $\hat{0}$ & 132 \\
\hline Prešov, Záhrada umenia & 265 & 84.5 & 18 & $15 \times 15$ & $\widehat{\sigma}$ & 133 \\
\hline Pribeník & 330 & 105.5 & 25 & $16 \times 22$ & $\widehat{0}$ & 168 \\
\hline Rakovice & 237 & 75.5 & 20 & $18 \times 15$ & 우 & 120 \\
\hline Slanec & 278 & 88.5 & 18 & $16 \times 14$ & $\hat{0}$ & 141 \\
\hline Súdovce & 302 & 96.5 & 14 & $12 \times 10$ & $\hat{\sigma}$ & 153 \\
\hline Tomášikovo & 315 & 100.4 & 25 & $16 \times 16$ & q & 162 \\
\hline Tomášov & 290 & 90.7 & 20 & $20 \times 19$ & 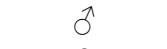 & 144 \\
\hline Topol'čianky & 225 & 71.7 & 20 & $16 \times 126$ & q & 114 \\
\hline Topol'čianky & 261 & 83.2 & 18 & $16 \times 16$ & 우 & 132 \\
\hline Topol'čianky & 305 & 97.5 & 12 & $14 \times 14$ & $\hat{0}$ & 155 \\
\hline Trávnica & 239 & 76.2 & 22 & $10 \times 8$ & q & 121 \\
\hline Trenčín & 365 & 116.7 & 16 & $12 \times 12$ & $\hat{0}$ & 185 \\
\hline Trenčín & 290 & 92.7 & 16 & $10 \times 10$ & q & 147 \\
\hline Turčianska Štiavnička & 233 & 74.2 & 24 & $9 \times 9$ & q & 118 \\
\hline Voderady & 292 & 93.0 & 18 & $18 \times 18$ & $\hat{0}$ & 148 \\
\hline
\end{tabular}

flowering process takes about a month, which is a time long enough to achieve phenological synchrony.

d) The male trees have a deep cut on the leaf blade and the female a shallow cut or none at all. e) Autumn foliage is earlier in male trees.

f) There was also observed a disproportion between the male and female seeds, unlike 1: 1 reported in the literature. 
g) There was found a unique - 135-year old female tree of G. biloba L. growing in Lučenec, on the locality of the company Ipel'ské tehelne. The tree is 12 heigh, with a trunk circumference $247 \mathrm{~cm}\left(\mathrm{~d}_{1.3}=79 \mathrm{~cm}\right)$, and crown width $12 \times 13 \mathrm{~m}$. This specimen exhibited, apart from the normally developed fruits on separate stalks, also fruits of almost the same size situated on the leaf blade, known as the middle fruit ("ohatsuki" - the fruit on the leaves) (Fig. 1).The occurrence of this type of fruit had previously only been recorded in Japan. The leaves were mostly fully grown (at 90\%), with no incisions on the leaf blade.

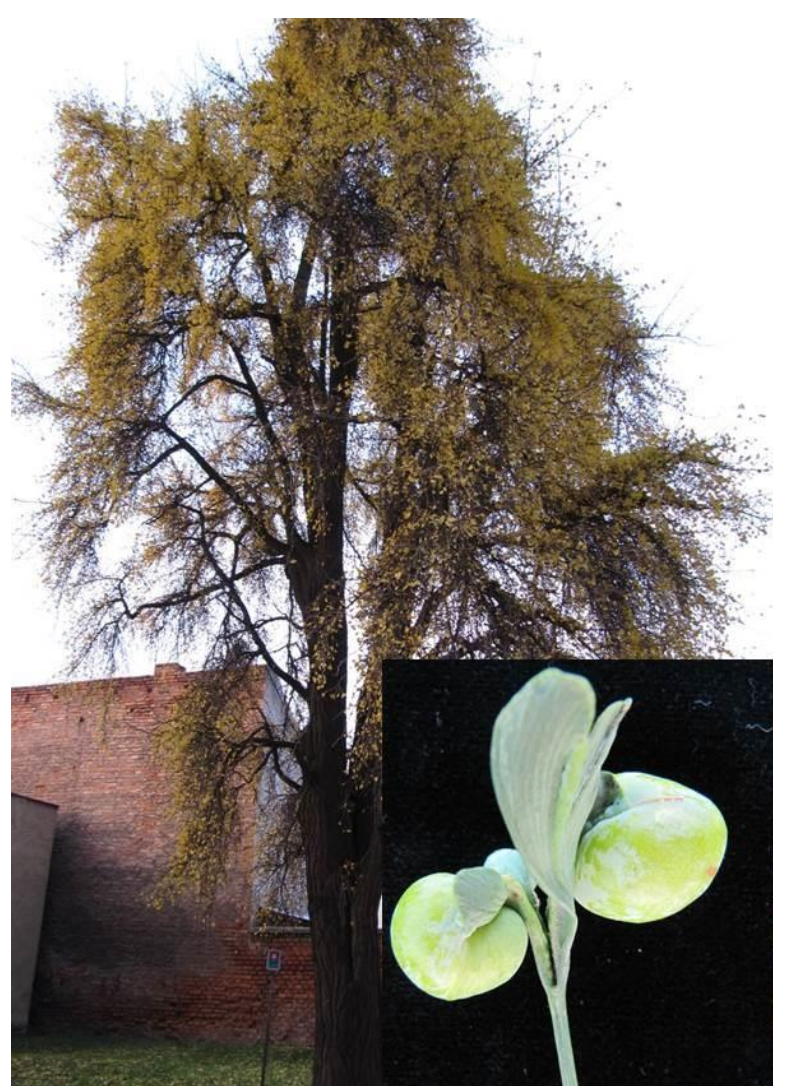

Fig. 1. Ginkgo biloba var. Ohatsuki in Lučenec.

\section{Genomic analyses}

In order to detect any possible relationship between the ecological microclimatic conditions for ginkgo trees growth and their DNA-microRNAs profiling, were selected twelve trees aged from 44 to 193 years (Table 1). Marker-based DNA fingerprinting specifically identifies the individuals and enables selecting the appropriate biological material for other applicable procedures. The applied types of miRNA markers were selected based on the studies by WANG et al. (2015) who identified a vast number of microRNAs in mature male and female ginkgo leaves, using transcriptomic analysis. The first type of miRNA markers (gb-miR160) belongs to the highly conserved miRNA class. The evolutionary conserved character of this class has a specific function in different physiological processes running in plants. The new miRNA family (gb-miR75) is a part of a specific regulation of defence processes. Another class of moderately conserved miRNAs (gb-miR482) are involved in the ginkgo defence mechanisms. Finally, the species-specific miRNA class (gb-miR5261) with no homologue in other plant species may be significant in producing new functions in the environmental and hormonal response (WANG et al., 2015).

In total, 339 fragments were amplified in twelve genotypes of ginkgo, with using four combinations of miRNAbased molecular markers. The number of fragments produced by one pair of primers ranged from 62 (gb-miR5261 forward/gb-miR5261 reverse) to 130 (gb-miR160 forward/ gb-miR75 reverse). The average number of fragments per a genotype ranged fro 5.2 (gb-miR5261 forward/gb-miR5261reverse) to 10.83 (gb-miR160 forward/gb-miR75 reverse). The amplification efficiency of individual markers was recorded through the total number of the amplified loci, the number of polymorphic and monomorphic loci as well as the percentage of polymorphism and polymorphic information content (PIC) (Table 4). The PIC values were higher than 0.5 in all types of miRNA markers used, and this indicated a high level of polymorphism. The values of the cophenetic correlation coefficients characterizing the results of cluster analysis were as follows; 0.93 (gbmiR160 F/gb-miR75 R, 0.95 (gb-miR482 F/gb-miR482 R) and 0.98 (gb-miR5261 F/gb-miR5261 R).

The oldest trees growing in the East of Slovakia, in the city of Košice (Masaryk Street) were characterized by a specific profile of their DNA fragments amplified by the applied markers. As the only one, the marker combining the conserved and the novel type of miRNAs markers (gb-miR160 F/gb-miR75 R) was able to differentiate a specific ginkgo cultivar Ohatsuki growing in Lučenec (Fig. 1). In the literature (ZHANG et al., 2015), this cultivar is also named as G. biloba var. epiphylla Mak. As we mentioned above, it is a unique female cultivar with fruits on the leaf blade. This type of cultivar had previously only been reported growing in Japan. The obtained results are in line with the finding of ZHANG et al. (2015) who identified a total of 82 miRNA sequences belonging to 23 families and 53 putative novel miRNAs. The expression analysis showed that 25 conserved and 21 novel miRNAs were differentially expressed between epiphyllous ovule leaves and normal leaves. To determine the functions of the identified miRNAs, putative target genes were predicted. The annotation showed that the target genes are involved in epiphyllous ovule formation. The most efficient marker can be supposed the moderately conserved type (gb-miR482 F/gb-miR482 R) providing the amplification of the genotype-unique miRNA profiles (Fig. 2). The genotypes from Hokovce (112 years), Palárikovo (160 years) and Košice (193 years) were characterized by unique miRNA marker profiles. Surprisingly, the youngest (44 years) evaluated genotype from Šurianky had a specific miRNA marker profile. This might be due to the 


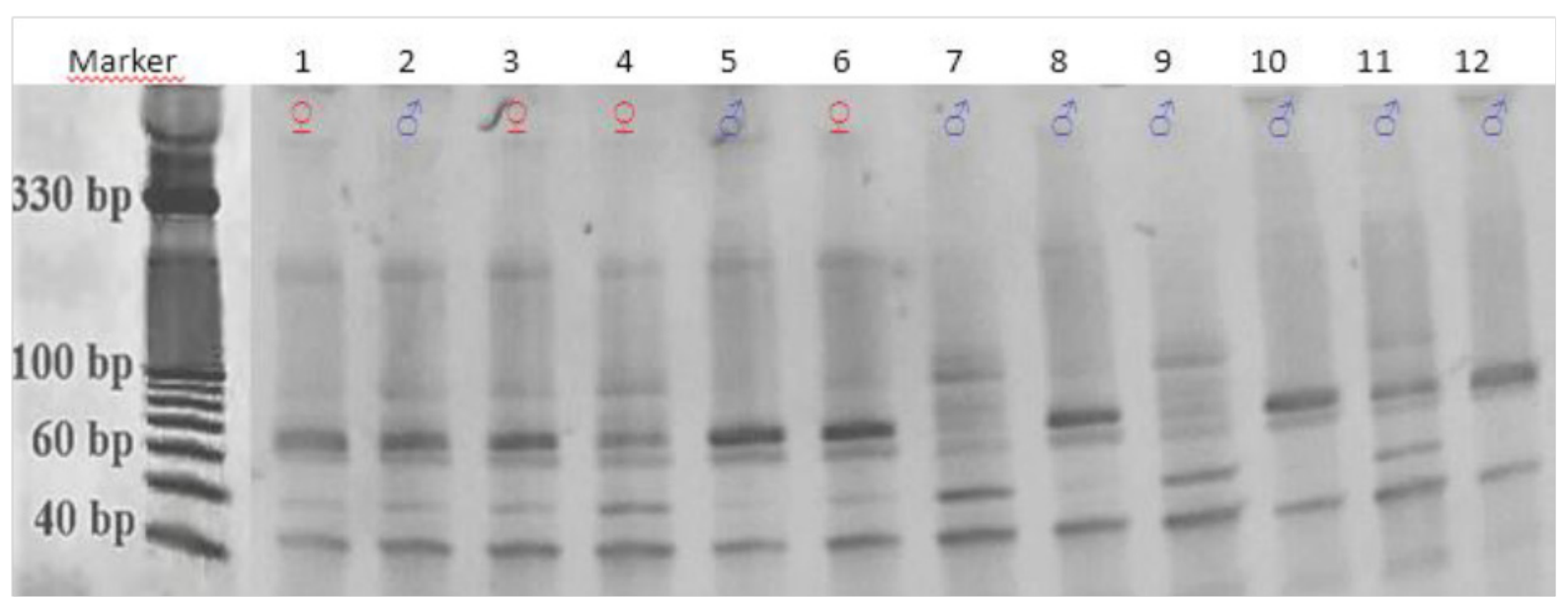

Fig. 2. Profiles of microRNA loci of Ginkgo biloba L. genotypes generated by marker gb-miR482. Marker - DNA ladder. Samples are numbered based on Table 1. + , female tree, $\hat{O}$, male tree.

character of the gb-miR482 family whose main function is connected with the defence mechanisms of plants $(\mathrm{HE}$ et al., 2015).

It is possible to summarise that young ginkgo trees (44-79 years) were characterised by the occurrence of unique DNA-miRNA fragments. On the contrary, within the group of the oldest ginkgo trees, it was possible to observe a high number of DNA fragments amplified by conservative miRNA markers.

Unique loci were recorded in young ginkgo trees, created specifically by the combination of highly conserved and new types of miRNA markers (gb-miR160 F/gbmiR75 R) in the genotype originating in central Slovakia, at 68 years and by the combination of species-specific miRNA markers (gb-miR5261 F/gb-miR5261 R) in genotypes originating from southern Slovakia (44 years) and eastern Slovakia (79 years).

The cluster analysis showed that young ginkgo trees, specifically the female genotypes from Vel'ký Blh (96 years) and Rimavská Sobota (68 years), originated from Central Slovakia, were clustered on one line under using a combination of high conserved and new types of miRNA markers (gb-miR160 F/gb-miR75 F), moderately conserved (gb-miR482 F/gb-miR482 F) and species-specific (gb-miR5261 F/gbmiR5261 R) miRNA markers.

As Figure 3 shows, based on the cluster analysis generated from DNA fragments amplified by markers of moderately conserved miRNA family, it was possible to associate the ginkgo trees with their locality.

Molecular DNA markers are an integral part of the evaluation process for assessing the genomes in significant plant genetic resources (Li et al., 2013). Markers of miRNA have a great potential in terms of the differentiation of closely related plant species, analysis of their genetic diversity and genetic mapping. The miRNA-based molecular marker system combines the advantages of polymorphism, reproducibility and transferability (Fu et al., 2013). Genomic characterization of miRNA molecules in $G$. biloba L. may provide insights into the miRNA-mediated

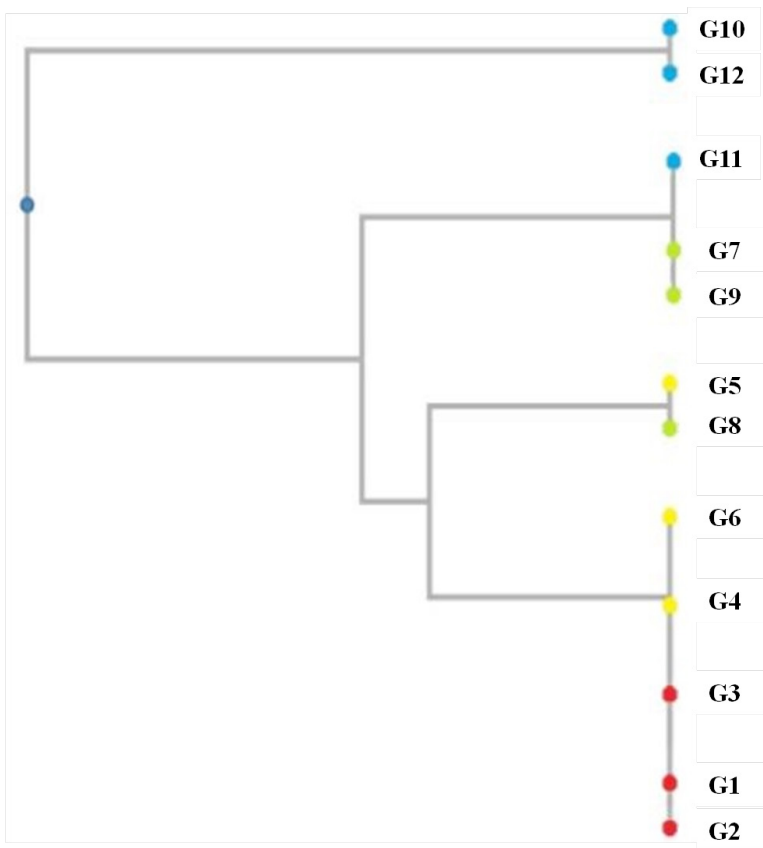

Fig. 3. Cluster analysis of Ginkgo biloba L. genotypes generated based on PCR amplification by gb-miR482 marker. The red color depicts genotypes from western, yellow from central, green from south and blue one from east Slovakia.

regulations of environmental adaptation in this species.

\section{Conclusion}

We have assembled the dendrometrical parameters and the age information of the oldest $45 \mathrm{G}$. biloba $\mathrm{L}$. trees grown in Slovakia. Based on long-term research we have also identified several morphological and physiological characters pointing to the tree gender. The genomic analyses unveiled the role of microRNA molecules in plant defence regulatory mechanism, as they enabled determining the 
Table 4. Discrimination parameters and characteristics of miRNA markers used in ginkgo genomic analysis

\begin{tabular}{ccccccc}
\hline $\begin{array}{c}\text { microRNA marker } \\
\text { combination }\end{array}$ & $\begin{array}{c}\text { Number } \\
\text { of loci }\end{array}$ & $\begin{array}{c}\text { Number of } \\
\text { polymorphic } \\
\text { loci }\end{array}$ & $\begin{array}{c}\text { Number of } \\
\text { monomorphic } \\
\text { loci }\end{array}$ & $\begin{array}{c}\text { Number } \\
\text { of unique } \\
\text { loci }\end{array}$ & $\begin{array}{c}\text { Percentage of } \\
\text { polymorphism }\end{array}$ & $\begin{array}{c}\text { PIC } \\
\text { value }\end{array}$ \\
\hline miR160 F/miR75 R & 14 & 7 & 6 & 1 & 50.00 & 0.92 \\
$\mathrm{miR} 160 \mathrm{~F} / \mathrm{miR} 75 \mathrm{~F}$ & 12 & 10 & 2 & 0 & 83.33 & 0.88 \\
$\mathrm{miR} 482 \mathrm{~F} / \mathrm{miR} 482 \mathrm{R}$ & 7 & 3 & 4 & 0 & 42.86 & 0.85 \\
$\mathrm{miR} 5261 \mathrm{~F} / \mathrm{miR} 5261 \mathrm{R}$ & 9 & 5 & 2 & 2 & 55.56 & 0.83 \\
\hline
\end{tabular}

specific miRNA-based profile of ginkgo genotypes grown in different localities of Slovakia. The cluster analysis has supported this observation. In addition, we identified the unique exemplar of ginkgo var. Ohatsuki grown in Lučenec, which has been previously recorded in Japan only.

\section{Acknowledgement}

This work was supported by the AgroBioTech Research Centre, the project „Building „AgroBioTech” Research Centre ITMS 26220220180“ (50\%) and the project ECOVA plus ITMS $26220120032(50 \%)$

\section{References}

Barlow, P., Kurczynska, E., 2007. The anatomy of the chi-chi of Ginkgo biloba suggests a mode of elongation growth that is an alternative to growth driven by an apical meristem. Journal of Plant Research, 120: 269-280.

BARTEL, D.P., 2004. MicroRNAs: genomics, biogenesis, mechanism, and function. Cell, 116: 281-297.

Barvkar, V.T., Pardeshi, V.C., Kale, S.M., Qiu, S., Rollins, M., Datla, R., Kadoo, N.Y., 2013. Genome-wide identification and characterization of microRNA genes and their targets in flax (Linum usitatissimum): characterization of flax miRNA genes. Planta, 237: 1149-1151.

Begović, B.M., 2010. Ginkgo biloba L. 1771. All about ginkgo (or maidenhair tree). Vol. 1. Pitomača: Self-publishing. 259 p. [cit. 2018-08-09]. http://www.scribd.com/ doc/74555470/Nature-s-Miracle-Ginkgo-Biloba Book1-Vol-1-2-B-M-Begovic-Bego

Bej, S., BasaK, J., 2014. MicroRNAs: the potential biomarkers in plant stress response. American Journal of Plant Sciences, 5: 748-759.

BENČAŤ, F., 1982. Atlas rozširenia cudzokrajných drevín na Slovensku a rajonizácia ich pestovania [Atlas of distribution of exotic woody species in Slovakia and zoning of their cultivation]. Bratislava: Veda. 368 p.

Fan, X.X., Shen, L., Zhang, X., Chen, X.Y., Fu, Ch.X., 2004. Assessing genetic diversity of Ginkgo biloba L. (Ginkgoaceae) populations from China by RAPD markers. Biochemical Genetics, 42: 7-8. 269-278.

Ferezliev, A., 2017. Relationship between particular dendrobiometrical indicators of natural European beech (Fagus sylvatica L.) dendrocenoses in Central Balkan Range. Folia Oecologica, 44 : 69-77.
Fu, D., Ma, B., Mason, A.S., XiaO, M., Wei, L. An, Z., 2013. MicroRNA-based molecular markers: a novel PCR-based genotyping technique in Brassica species. Plant Breeding, 132: 375-381.

Ganie, S.A., Mondal, T.K., 2015. Genome-wide development of novel miRNA-based microsatellite markers of rice (Oryza sativa) for genotyping applications. Molecular Breeding, 35: 1-12.

Garcia-Vallve, S., Palau, J., Romeu, A., 1999. Horizontal gene transfer in glycosyl hydrolases inferred from codon usage in Escherichia coli and Bacillus subtilis. Molecular Biology and Evolution, 16: 1125-1134.

Han, S., Wu, Z., Jin, Y., YANG, W., ShI, H., 2015. RNA-Seq analysis for transcriptome assembly, gene identification, and SSR mining in ginkgo (Ginkgo biloba L.). Tree Genetics and Genomes, 11: 37.

He, B., Gu, Y., Xu, M., Wang, J., CaO, F., Xu, L., 2015. Transcriprome analysis of Ginkgo biloba kernels. Frontiers in Plant Science, 6: 819.

Hlavačková, L., Nôžková, J., Porokhovinova, E., Brutch, N., Shelenga, T., BJelková, M. RaŽNÁ, K., 2016. Analysis of miRNA polymorphism during the selected developmental processes of flax. Journal of Central European Agriculture, 17: 707-724.

Hrubík, P., Kollár, J., Rovná, K., Tkáčová, S., MŇAHONČÁKovÁ, E., 2011. Kvalitatívna inventarizácia, klasifikácia a hodnotenie zdravotného stavu drevín pre účely záhradno-architektonickej a krajinárskej tvorby [Qualitative inventory, classification and assessment of health state of woody plants with purpose of their use in garden and landscape design prosome]. Nitra: Slovenská pol'nohospodárska univerzita. $99 \mathrm{p}$.

Jones-Rhoades, M. W., Bartel, D. P., Bartel, B., 2006. MicroRNAs and their regulatory roles in plants. Annual Review of Plant Biology, 57:19-53.

Kolařík, J., Martinková, M., Čermák, M., Gebauer, R., Špinlerová, Z., Dienstbier, F., Horáček, P., Praus, L., Cudlín, P., KrejČIř́ík, P., Reš, B., Romanský, M., JaNKOvSKÝ, L., BerÁNeK, J., LičKA, D., WeSSOLLY, L., 2010. Péče o dřeviny rostouci mimo les [Cultivation of woody plants growing outside forest stands]. 2nd vol. Vlašim: ČSOP. 720 p.

Kruszka, K., Pieczynski, M., Windels, D., Bielewicz, D., Jarmolowski, A., SzWeykowska-Kulinska, Z., VaZQUEZ, F., 2012. Role of microRNAs and other sRNAs of plants in their changing environments. Journal of Plant Physiology, 169: 1664-1672.

Li, G.P., Zhang, C.Q., CAO, F.L., 2013. An efficient approach to identify Ginkgo biloba cultivars by using random amplified polymorphic DNA markers with a manual cul- 
tivar identification diagram strategy. Genetics and Molecular Research, 12 (1): 175-182.

Li, Y.Y., Zhang, L.P., Chen, X.Y. 2009. Development of polymorphic microsatellite markers for Ginkgo biloba L. by database mining. Conservation Genetics Resources, 1:81-83.

Liao, L., LiU, J., Dai, Y., Li, X., Xie, M., Chen, Q., Yin, H., QIU, G., LiU, X., 2009. Development and application of SCAR markers for sex identification in the dioecious species Ginkgo biloba L. Euphytica. 169 (1): 49-55.

Lin, X., Zhang, J., Li, Y., Luo, H., Wu, Q., Sun, CH., Song, J., Li, X., Wei, J., Lu, A., Qian, Z., Khan, I.A., Chen, S., 2011. Functional genomics of a living fossil tree, Ginkgo, based on next-generation sequencing technology. Physiologia Plantarum, 143: 207-218.

Mei, Z., Khan, M. A., Zeng, W., Fu, J., 2014. DNA fingerprints of living fossil Ginkgo biloba by using ISSR and improved RAPD analysis. Biochemical Systematics and Ecology, 57: 332-337.

MohantA, T.K., 2012. Advances in Ginkgo biloba research. Genomics and metabolomics perspectives. African Journal of Biotechnology. 11: 15936-15944.

Mondal, T.K., Ganie, S.A., 2014. Identification and characterization of salt responsive miRNA-SSR markers in rice (Oryza sativa). Gene, 535: 204-209.

Neutelings, G., Fénart, S., Lucau-Danila, A., Hawkins, S., 2012. Identification and characterization of miRNA and their potential targets in flax. Journal of Plant Physiology, 169: 1754-1766.

Padmalatha, K., Prasad, M.N.V., 2006. Optimization of DNA isolation and PCR protocol for RAPD analysis of selected medicinal and aromatic plants of conservation concern from Peninsular India. African Journal Biotechnology, 5: 230-234.

RaŽNÁ, K., HrubíK, P., 2016. Ginkgo dvojlaločné (Ginkgo biloba L.) - genomická štúdia a kultúrne rozširenie na Slovensku [Ginkgo biloba L. - genomic study and cultural area of expansion in Slovakia]. Nitra: Slovenská pol’nohospodárska unvierzita. $92 \mathrm{p}$.

RaŽná, K., HrubíK, P., ŽiarovskÁ, J., Kollár, J., Kullačová, D., Pavel, J., Štefúnová, V., 2014. Kultúrne rozširenie ginka dvojlaločného (Ginkgo biloba L.) na Slovensku a hodnotenie jeho variability pomocou DNA markérov [Cultural area of expansion of Ginkgo biloba L. in Slovakia and assessments of this species variability with using DNA markers]. Nitra: Slovenská pol'nohospodárska univerzita. $95 \mathrm{p}$.

Ražná, K., NôžKová, J., HlavačKová, L., Brutch, N., Po- rokhovinova, E., Shelenga, T., Pavlov, A., 2015. Genotyping of flax genetic resources by miRNA-based molecular markers and morphology. Agriculture, 61: 129-138.

Šmarda, P., Horová, L., KNáPeK, O., Dieck, H., Dieck, M., Ražná, K., Hrubík, P., Orlóci, L., Papp, L., Veselá, K., VeselÝ, P., BuREŠ, P., 2018. Multiple haploids, triploids, and tetraploids found in modern-day "living fossil" Ginkgo biloba. Horticulture Research, 5: 55.

Šmarda, P., Veselý, P., Šmerda, J., Bureš, P., KnáPeK, O., ChytrÁ, M., 2016. Polyploidy in a "living fossil" Ginkgo biloba. New Phytologist, 212: 11-14.

VAn Beek, T. A. (eds), 2000. Ginkgo biloba. Amsterdam: Taylor and Francis e-Library. 523 p. ISBN 0-203-34306-9

Uhrin, P., Supuka, J., Billiková, M. 2018. Adaptability of Norway maple (Acer platanoides L.) to urban environment. Folia Oecologica, 45: 33-45.

Zhang, Q., Li, J., SANG, Y., XING, S., Wu, Q., Liu, X., 2015. Identification and characterization of MicroRNAs in Ginkgo biloba var. epiphylla Mak. PLoS ONE, 10 (5): e0127184.

ZitTLAU, J. 2007. Liečivo ginkgo [Medicinal product ginkgo]. Bratislava: Noxi. 96 p.

Wang, L., Zhao, J., Zhang, M., Weixin, L., Luo, K., Lu, Z., ZHANG, CH., JiN, B., 2015. Identification and characterization of microRNA expression in Ginkgo biloba L. leaves. Tree Genetics \& Genomes, 11: 76.

WANG, M., WANG, Q., WANG, B., 2012. Identification and characterization of microRNAs in Asiatic cotton (Gossypium arboreum L.). Plos One, 7: 4.

Yadav, C.B.Y., Muthamilarasan, M., Pandey, G., Prasad, M., 2014. Development of novel microRNA-based genetic markers in foxtail millet for genotyping applications in related grass species. Molecular Breeding, 34: 22192224.

Yan, X.L., Chen, Y.Y., Guan, B. C., Fu, Ch. X., 2009. Eleven novel microsatellite markers developed from the living fossil Ginkgo biloba L. (Ginkgoaceae). Conservation Genetics, 10: 1277-1279.

Yan, X.F., Lian, C.L., Hogetsu, T., 2006. Development of microsatellite markers in ginkgo (Ginkgo biloba L.). Molecular Ecology Notes, 6: 301-302.

YANG, H., GAN, S.M., YIN, G.T., Xu, H.C., 2005. Identification of random amplified polymorphic DNA markers linked to sex determination in Calamus simplicifolius C. F. Wei. Journal of Integrative Plant Biology, 47 (10): 1249-1253.

Received September 27, 2018 Accepted April 8, 2019 